\title{
Synthesis and In Vitro Evaluation of Novel Nortropane Derivatives as Potential Radiotracers for Muscarinic $\mathbf{M}_{2}$ Receptors
}

\author{
Remco J. J. Knol, ${ }^{1}$ Jan C. van den Bos, ${ }^{2,3}$ Anton G. M. Janssen, ${ }^{3}$ Kora de Bruin, ${ }^{4}$ \\ Berthe L. F. van Eck-Smit, ${ }^{4}$ and Jan Booij ${ }^{4}$ \\ ${ }^{1}$ Department of Nuclear Medicine, Medical Center Alkmaar, Wilhelminalaan 12, $1815 \mathrm{JD}$ Alkmaar, The Netherlands \\ ${ }^{2}$ Department of Organic Chemistry, Eindhoven University of Technology, Den Dolech 2, 5600 MB Eindhoven, The Netherlands \\ ${ }^{3}$ GE Healthcare, Cygne Center, De Rondom 8, 5612 AP Eindhoven, The Netherlands \\ ${ }^{4}$ Department of Nuclear Medicine, Academic Medical Center, University of Amsterdam, Meibergdreef 9 , \\ 1105 AZ Amsterdam, The Netherlands
}

Correspondence should be addressed to Remco J. J. Knol, r.j.j.knol@mca.nl

Received 24 November 2010; Revised 3 March 2011; Accepted 25 March 2011

Academic Editor: Guy Bormans

Copyright (C) 2011 Remco J. J. Knol et al. This is an open access article distributed under the Creative Commons Attribution License, which permits unrestricted use, distribution, and reproduction in any medium, provided the original work is properly cited.

\begin{abstract}
Disturbances of the cerebral cholinergic neurotransmitter system are present in neurodegenerative disorders. SPECT or PET imaging, using radiotracers that selectively target muscarinic receptor subtypes, may be of value for in vivo evaluation of such conditions. $6 \beta$-acetoxynortropane, a potent muscarinic $\mathrm{M}_{2}$ receptor agonist, has previously demonstrated nanomolar affinity and high selectivity for this receptor. Based on this compound we synthesized four nortropane derivatives that are potentially suitable for SPECT imaging of the $\mathrm{M}_{2}$ receptor. $6 \beta$-acetoxynortropane and the novel derivatives were tested in vitro for affinity to the muscarinic $\mathrm{M}_{1-3}$ receptors. The original $6 \beta$-acetoxynortropane displayed high affinity $\left(K_{i}=70-90 \mathrm{nM}\right)$ to $\mathrm{M}_{2}$ receptors and showed good selectivity ratios to the $\mathrm{M}_{1}$ (65-fold ratio) and the $\mathrm{M}_{3}$ (70-fold ratio) receptors. All new derivatives showed reduced affinity to the $\mathrm{M}_{2}$ subtype and loss of subtype selectivity. It is therefore concluded that the newly synthesized derivatives are not suitable for human SPECT imaging of $\mathrm{M}_{2}$ receptors.
\end{abstract}

\section{Introduction}

Central cholinergic disturbances are present in many neuropsychiatric and neurodegenerative diseases. In various forms of dementia, such as Alzheimer's dementia (AD) or Lewy body dementia, cholinergic deficits in the brain $[1,2]$ are associated with cognitive decline [3-5] and are thought to precede clinical symptoms.

The majority of the cholinergic deficits in these diseases arise from degenerative events in basal forebrain regions such as the nucleus basalis of Meynert [6,7], which provides the cholinergic input of the cerebral cortex. In degenerative diseases such as $\mathrm{AD}$, disruption of basal cholinergic forebrain projections leads to a presynaptic cholinergic defect in cortical brain areas $[1,8]$. Being part of a family of five muscarinic receptor subtypes, the muscarinic $\mathrm{M}_{2}$ receptor is located predominantly presynaptically [9] and is consequently a potential target for the evaluation of the integrity of the cholinergic neurotransmitter system by molecular imaging.

In vivo assessment of the central cholinergic system in patients suffering from dementia by means of positron emission tomography (PET) or single photon emission computed tomography (SPECT) may be of value for early diagnosis or monitoring of such diseases, to predict response to cholinergic therapies (such as acetylcholinesterase inhibitors) or to evaluate effects of experimental drugs. Molecular imaging of the cholinergic system of the brain requires radiotracers that ideally selectively target specific neuroreceptors of this neurotransmitter system, such as the muscarinic $\mathrm{M}_{2}$ receptor.

Many attempts have been made to develop muscarinic receptor subtype selective radiotracers [10-12]. Currently, amongst the most promising of these potential tracers is $\left[{ }^{18} \mathrm{~F}\right]$ FP-TZTP $[10,13,14]$, which has selectivity for the 
muscarinic $\mathrm{M}_{2}$ receptor [15] and has been applied successfully in several human PET studies [16-18].

Iodine-123 has favorable properties for SPECT imaging of neuroreceptors [19-23]. The abundant $159 \mathrm{keV} \gamma$ photons of ${ }^{123} \mathrm{I}$ (83\% abundancy) are suitable for high-resolution brain SPECT imaging using LEHR (Low Energy High Resolution) or fanbeam collimators. Furthermore, unlike ${ }^{18} \mathrm{~F}$ labeled radiopharmaceuticals $\left(T_{1 / 2}=109.8 \mathrm{~min}\right)$, the halflife of 13.2 hours permits transportation over long distances of centrally produced ${ }^{123} \mathrm{I}$-labeled radiopharmaceuticals, for instance, to the majority of European nuclear medicine centers from a single manufacturing site. Moreover, suitable methods have been developed for convenient radiosynthesis of radiopharmaceuticals labeled with ${ }^{123}$ I selectively at one appropriate position with high radiochemical yields, for instance, by oxidative iododestannylation [24]. However, radioiodinated SPECT analogues of TZTP so far have demonstrated disappointing results in vivo [25]. Radioiodinated Z-IQNP is another compound that has recently been evaluated for imaging of the muscarinic $M_{2}$ receptor [12, 26], although the muscarinic subtype selectivity of this compound for the $\mathrm{M}_{2}$ receptor subtype is limited.

Recently, $6 \beta$-acetoxynortropane, a tropane alkaloid, was reported to be a potent and highly selective agonist for muscarinic $\mathrm{M}_{2}$ receptors [27], and radiolabeled derivatives of this compound may thus be of value for in vivo imaging of these receptors. Moreover, as compared with the mentioned TZTP analog these nortropane analogs have favorable physicochemical properties. Notably, the lipophilicity of iodinated nortropane compounds remains in the optimal range $1-3$ of $\log D(\mathrm{pH} 7.4)$. The $\log D(\mathrm{pH} 7.4)$ of iodinated TZTP compounds, on the other hand, is too high (i.e., $>4$ ), likely resulting in a high degree of nonspecific binding in the brain. In order to obtain good in vivo stability, the iodine label should be bound to an sp2-carbon, where iodoallyland iodophenyl compounds are the most suitable candidates. Of these, iodophenyl compounds are synthetically the most accessible and more stable.

Based on $6 \beta$-acetoxynortropane, we synthesized four derivatives as potential radiotracers for use in SPECT imaging. The four synthesized nortropane derivatives were tested for affinity to cloned human muscarinic $M_{1}-M_{3}$ receptor subtypes on membrane fractions of Chinese hamster ovary $(\mathrm{CHO})$ cells by in vitro competitive binding assays.

\section{Material and Methods}

Two nortropane analogues with an iodine containing moiety on the $6 \beta$-position have been synthesized. The tropane skeleton was formed in a single-step multicomponent reaction in analogy to the classical Robinson tropinone synthesis $[28,29]$, as displayed in Figure 1. The resulting tropinone was reduced under Wolff-Kishner conditions to give 6-hydroxy$\mathrm{N}$-benzylnortropane (3). Alkylation or acylation of the hydroxyl function of 3 resulted in $4 \mathbf{a}-\mathbf{c}$, which were debenzylated in two steps $[29,30]$ to provide the previously described $6 \beta$-acetoxynortropane (5a), and its iodinated analogues, the
$6 \beta-4^{\prime}$-iodobenzyl ether $(5 \mathbf{b})$ or the $6 \beta-4^{\prime}$-iodobenzoate ester (5c) of $6 \beta$-nortropinol, respectively.

Accordingly, a bromophenyl ring was introduced at the $3 \beta$-position. First, the 6-hydroxyfunction of tropinone (2) was protected as tert-butyldimethylsilyl ether. With a Grignard reaction 4-bromophenyl was introduced at the $\mathrm{C} 3$ of the tropane. According to the signal of the $\mathrm{C} 6 \alpha-\mathrm{H}$ in the proton NMR spectrum, only the isomer with the 4-bromophenyl in the equatorial position had been formed. Desilylation followed by acetylation yielded $3 \beta$-(4-bromophenyl)-6 $\beta$ acetoxy-N-benzyl nortropane (9).

The benzyl group was removed by hydrogenation, but simultaneously also the bromo substituent was removed to result in $3 \alpha$-hydroxy- $3 \beta$-phenyl- $6 \beta$-acetoxy-nortropane (10b). In one occasion also the $3 \beta$-phenyl-6 $\beta$-acetoxy-nortropane (10a) was isolated, presumably due to the presence of a small amount of acid.

Relative binding affinity and selectivity ratios of the various nortropane derivatives for the $\mathrm{M}_{1}-\mathrm{M}_{3}$ were determined by competitive binding assays against $\left[{ }^{3} \mathrm{H}\right] \mathrm{N}$-methylscopolamine $\left(\left[{ }^{3} \mathrm{H}\right] \mathrm{NMS}\right.$, Perkin Elmer, Waltham, USA; specific activity $78 \mathrm{Ci}(2886 \mathrm{GBq}) / \mathrm{mmol})$. Assays were performed on membrane suspensions from $\mathrm{CHO}$ cells expressing either the recombinant human muscarinic $M_{1}, M_{2}$, or the $M_{3}$ receptor subtype (Perkin Elmer, Waltham, USA) [25].

In the competitive binding assays, incubation buffer contained $50 \mathrm{mM}$ TRIS- $\mathrm{HCl}, 10 \mathrm{mM} \mathrm{MgCl}_{2}$, and $1 \mathrm{mM}$ EDTA $\left(\mathrm{pH} 7.4\right.$ at $\left.4^{\circ} \mathrm{C}\right)$. The assays were incubated during $60 \mathrm{~min}$ $\left(\mathrm{M}_{1}\right.$ or $\mathrm{M}_{2}$ receptor subtypes) or $120 \mathrm{~min}\left(\mathrm{M}_{3}\right.$ receptor subtypes) at $27^{\circ} \mathrm{C}$. Nonspecific binding was determined using atropine as a competitor in a concentration of $1 \mu \mathrm{M}$.

In the first series of competitive binding assays, the $6 \beta$ $4^{\prime}$-iodobenzyl ether $(\mathbf{5 b})$ and the $6 \beta-4^{\prime}$-iodobenzoate ester (5c) of $6 \beta$-nortropinol, as well as the lead compound $6 \beta$ acetoxynortropane (5a), were tested. Protein concentrations for undiluted receptor subtype suspensions were $1.2 \mathrm{mg} / \mathrm{mL}$ $\left(\mathrm{M}_{1}\right), 4.3 \mathrm{mg} / \mathrm{mL}\left(\mathrm{M}_{2}\right)$, and $2.0 \mathrm{mg} / \mathrm{mL}\left(\mathrm{M}_{3}\right)$. Aliquots $(n=3)$ of diluted membranes (factor $1: 100)$ containing the $M_{1}-M_{3}$ receptor subtypes were incubated in a total volume of $540 \mu \mathrm{L}$ containing $500 \mu \mathrm{L}$ diluted membranes, $20 \mu \mathrm{L}\left[{ }^{3} \mathrm{H}\right] \mathrm{NMS}$, and $20 \mu \mathrm{L}$ of the nortropanes in increasing concentrations. The $\left[{ }^{3} \mathrm{H}\right] \mathrm{NMS}$ was used in a final concentration of $0.2 \mathrm{nM}$ for the $M_{1}$ and $M_{2}$ assays and $0.09 \mathrm{nM}$ for the $\mathrm{M}_{3}$ assays. The equilibrium dissociation constants in $\mathrm{nM}$ of $\left[{ }^{3} \mathrm{H}\right] \mathrm{NMS}$ for the three receptor subtypes, provided by the manufacturer, were $0.15\left(\mathrm{M}_{1}\right), 0.19\left(\mathrm{M}_{2}\right)$, and 0.08 $\left(\mathrm{M}_{3}\right)$. Final competitor concentrations ranged from 1.0 . $10^{-10} \mathrm{M}$ to $1.0 \cdot 10^{-4} \mathrm{M}$. After incubation, the reaction was rapidly terminated by vacuum filtration over GF/C glass fiber filters, presoaked in $0.3 \%$ polyethylenimine (SigmaAldrich, Munich, Germany), and washed 5 times with $1 \mathrm{~mL}$ of ice-cold buffer. Filters were placed in vials with $10 \mathrm{~mL}$ of scintillation fluid (Ultima Gold, Perkin Elmer, Waltham, USA) and counted in a liquid scintillation counter (Tri-Carb 2900 TR Liquid Scintillation Analyzer, Packard. Software version: 3100$)$.

In the second series of competitive binding assays, derivative $\mathbf{1 0 a}$ and $\mathbf{1 0 b}$ and the lead compound $6 \beta$-acetoxynortropane $(\mathbf{5 a})$ were tested. In this series, the protein 

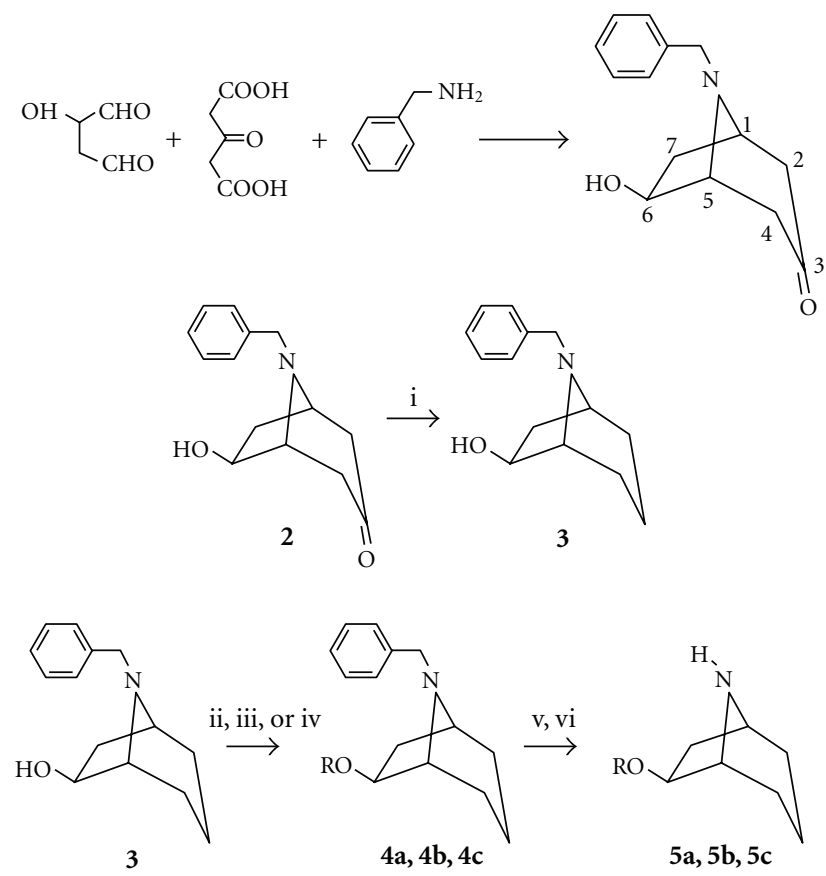

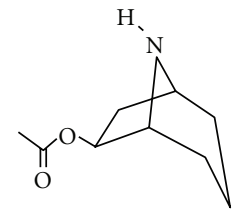

$5 a$

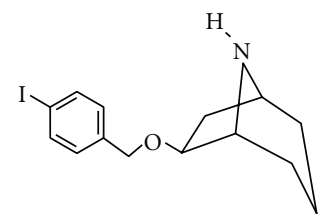

$5 b$<smiles>O=C(OC1CC2CCCC1N2)c1ccc(I)cc1</smiles>

$5 c$

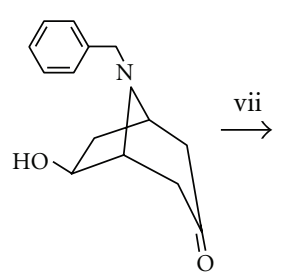

2

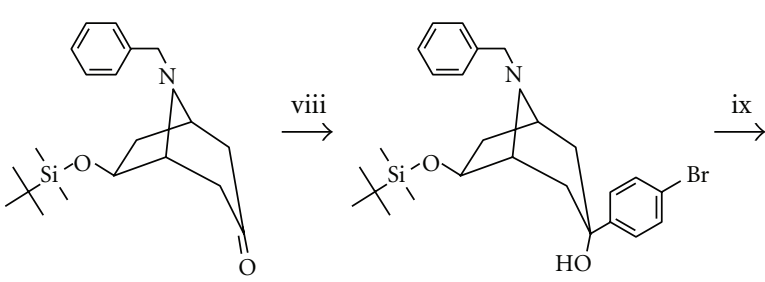

7<smiles>OC1CCC2CC(O)CC(C1)C2Nc1ccccc1</smiles>

$\downarrow x$<smiles>CC(=O)OC1CCC2CCC(C1)C2c1ccccc1</smiles>

$10 b$<smiles>CC(=O)OC1CCC2CC(O)CC(C1)C2Cc1ccccc1</smiles>

10a<smiles>CC(=O)OC1CCC2CC(O)CC(C1)C2Nc1ccccc1</smiles>

Figure 1: Reagents and conditions: (i) $\mathrm{NH}_{2} \mathrm{NH}_{2}, \mathrm{NaOH}$; (ii) $\mathrm{Ac}_{2} \mathrm{O}$, pyridine; (iii) 4-Iodobenzyl bromide, DMF; (iv) 4-Iodobenzoyl chloride, DMAP, $\mathrm{Et}_{3} \mathrm{~N}, \mathrm{CH}_{2} \mathrm{Cl}_{2}$; (v) $\alpha$-chloroethyl chloroformate, Toluene; (vi) MeOH; (vii) TBDMSCl, DMAP, Et ${ }_{3} \mathrm{~N}$, DMF; (viii) Mg, 1,4dibromobenzene, THF; (ix) $\mathrm{HCl}(2 \mathrm{M})$, THF, EtOH (1/1/1); (x) $\mathrm{Ac}_{2} \mathrm{O}$, pyridine; (xi) $\mathrm{H}_{2}$, Pd/C. Variants 4a-c: $\mathrm{R}(\mathbf{a}) \mathrm{CH}_{3} \mathrm{CO},(\mathbf{b}) p$ - $\mathrm{IPhCH}_{2}$, and (c) $p$-IPhCO. 
concentrations for undiluted receptor subtype suspensions were $0.6 \mathrm{mg} / \mathrm{mL}\left(\mathrm{M}_{1}\right), 7.5 \mathrm{mg} / \mathrm{mL}\left(\mathrm{M}_{2}\right)$, and $1.5 \mathrm{mg} / \mathrm{mL}$ $\left(\mathrm{M}_{3}\right)$. Aliquots $(n=4)$ of diluted membranes (factor $1: 30$ ) containing the $M_{1}, M_{2}$, or $M_{3}$ receptor subtype were incubated on a microplate in volumes of $190 \mu \mathrm{L}$ containing $150 \mu \mathrm{L}$ diluted membranes, $20 \mu \mathrm{L}\left[{ }^{3} \mathrm{H}\right] \mathrm{NMS}$, and $20 \mu \mathrm{L}$ of the nortropanes in increasing concentrations. In these assays, the $\left[{ }^{3} \mathrm{H}\right] \mathrm{NMS}$ was used in a final concentration of $0.13 \mathrm{nM}$ for the $M_{1}$ and $M_{2}$ assays and $0.065 \mathrm{nM}$ for the $\mathrm{M}_{3}$ assays. The $K_{d}$ in nM of $\left[{ }^{3} \mathrm{H}\right] \mathrm{NMS}$ in these experiments were as stated above. Final competitor concentrations ranged from $1.0 \cdot 10^{-10} \mathrm{M}$ to $1.0 \cdot 10^{-5} \mathrm{M}$. After incubation, the assays were filtrated over UniFilter $96 \mathrm{GF} / \mathrm{C}$ filter plates, presoaked in $0.3 \%$ polyethylenimine (Sigma-Aldrich, Munich, Germany), and washed 9 times with $200 \mu \mathrm{L}$ of ice-cold buffer. $30 \mu \mathrm{L}$ of scintillation fluid (MicroScint, Perkin Elmer, Waltham, USA) was added, and the filter plates were counted in a liquid scintillation counter (TopCount 5.0 Liquid Scintillation Analyzer, Perkin Elmer, Waltham, USA). For each competitor, the inhibition constant $\left(K_{i}\right)$ was calculated from the $\mathrm{EC}_{50}$ for the muscarinic $\mathrm{M}_{1}, \mathrm{M}_{2}$, and $\mathrm{M}_{3}$ subtypes with nonlinear regression curve fitting using Graphpad Prism (version 3.02), relative to the $K_{d}$ of $\left[{ }^{3} \mathrm{H}\right] \mathrm{NMS}$ as provided by the manufacturer.

\section{Results}

In Figure 2, the results of the competitive binding experiments are displayed. The affinity of $6 \beta$-acetoxynortropane, relative to $\left[{ }^{3} \mathrm{H}\right] \mathrm{NMS}$, for the muscarinic $\mathrm{M}_{2}$ receptor subtype proved to be high in both experiments. In the first experiment the $K_{i}$ of $6 \beta$-acetoxynortropane was determined as $88.1 \pm 23.8 \mathrm{nM}$ (average $\pm \mathrm{SD} ; n=3$ ) and in the second experiment as $71.6 \pm 4.8 \mathrm{nM}$ (average $\pm \mathrm{SD} ; n=4$ ). In our experiments, selectivity ratios of the compound for the $\mathrm{M}_{2}$ over $M_{1}$ or $M_{3}$ receptor subtype proved to be approximately 65 and 70, respectively.

The $6 \beta-4^{\prime}$-iodobenzyl ether of $6 \beta$-nortropinol (5b) performed substantially less than $6 \beta$-acetoxynortropane and displayed a $K_{i}$ of only $3.0 \pm 0.7 \mu \mathrm{M}$, while selectivity for the $\mathrm{M}_{2}$ receptor was lost. The selectivity ratios of this derivative for the $M_{2}$ over the $M_{1}$ and $M_{3}$ receptors of the compound were determined as 0.1 and 0.2 , respectively.

The $6 \beta-4^{\prime}$-iodobenzoate ester of $6 \beta$-nortropinol (5c) also performed less than $6 \beta$-acetoxynortropane, and a $K_{i}$ of $6.8 \pm 1.5 \mu \mathrm{M}$ was estimated for the $\mathrm{M}_{2}$ receptor, while selectivity ratios over the $M_{1}$ and $M_{3}$ receptor, were determined as 0.6 and 2.0, respectively.

The second series of experiments (Figure 2), using $3 \beta$-phenyl-6 $\beta$-acetoxynortropane (10a) and $3 \alpha$-hydroxy- $3 \beta$ phenyl-6 $\beta$-acetoxynortropane (10b) as competitors, likewise showed weak affinity for muscarinic receptors, and small competitive effects to the binding of $\left[{ }^{3} \mathrm{H}\right] \mathrm{NMS}$ were only detected at the highest concentration of the tested range. The affinity for the muscarinic receptors could therefore not be assessed for these two derivatives.

\section{Discussion}

In the present study, we have synthesized derivatives that are based on $6 \beta$-acetoxynortropane, a tropane alkaloid described by Pei and coworkers, which was shown to be a muscarinic agonist with high affinity to muscarinic $\mathrm{M}_{2}$ receptor subtypes, but lower affinity to other muscarinic receptor subtypes [27]. Due to the apparent selectivity of $6 \beta$-acetoxynortropane for the $\mathrm{M}_{2}$ receptor, the compound may be of interest for use as a muscarinic receptor radiotracer.

Two analogues of the tracer were synthesized in which the acetyl ester moiety on the $6 \beta$-position was replaced by either $4^{\prime}$-iodobenzyl ether $(5 \mathbf{b})$ or a $4^{\prime}$-iodobenzoate ester $(\mathbf{5 c})$. The competitive binding assays demonstrated that the substitution on the $6 \beta$-position of the tropane skeleton had shifted the affinity from the nanomolar range to the micromolar range and that the selectivity of the alkaloid for the $\mathrm{M}_{2}$ receptor subtype was lost. Therefore, two other analogues were synthesized retaining the $6 \beta$ acetoxy function, with substitution of a phenyl moiety on the $3 \beta$-position of the tropane skeleton: $3 \beta$-phenyl$6 \beta$-acetoxynortropane (10a) and $3 \alpha$-hydroxy- $3 \beta$-phenyl- $6 \beta$ acetoxynortropane (10b). Unfortunately, these derivatives demonstrated even less favorable affinity for the three tested muscarinic receptor subtypes.

The challenge of the present study was to create a derivative of $6 \beta$-acetoxynortropane that is suitable for (radio)iodination, while preserving the affinity for the $\mathrm{M}_{2}$ receptor, optimizing lipophilicity to allow optimal bloodbrain-barrier $(\mathrm{BBB})$ penetration and to limit nonspecific uptake, maintaining the size of the molecule as small as possible, while not compromising metabolic stability.

In an earlier study, our group evaluated the potential $\mathrm{M}_{2}$ receptor tracer E-iodopentenyl-thio-TZTP, which showed moderate selectivity for the muscarinic $\mathrm{M}_{2}$ receptor over the $M_{1}$ and $M_{3}$ receptors in vitro [25], although selectivity for $\mathrm{M}_{2}$ receptors was less than the original FP-TZTP $[10,14]$. However, in vivo experiments using the TZTP derivative proved to be unsuccessful due to high lipophilicity of the tracer and very rapid metabolism of the parent compound $[10,14]$. The $6 \beta$-acetoxynortropane derivatives that were synthesized and evaluated in the present study have several advantages over the earlier tested TZTP derivative(s). The lipophilicity of derivative $\mathbf{5 b}$ and $\mathbf{5} \mathbf{c}$ or iodinated analogues of $\mathbf{1 0 a}$ and $\mathbf{1 0 b}$ is less than that of the earlier synthesized TZTPs, being within the estimated $\log P(P=$ partition coefficient in octanol-buffer at $\mathrm{pH}$ 7.4) range between 1 and 2 (data not shown), which is considered to be optimal for penetration of the $\mathrm{BBB}$. Incorporation of an ester function such as in the $6 \beta-4^{\prime}$-iodobenzoate ester of $6 \beta$-nortropinol (5c), $3 \beta$-phenyl$6 \beta$-acetoxynortropane (10a) or an additional hydroxyl group in $3 \alpha$-hydroxy- $3 \beta$-phenyl-6 $\beta$-acetoxynortropane (10b) contributes to the reduction in lipophilicity as compared to the earlier reported TZTPs, which should theoretically limit nonspecific uptake of these potential tracers in the brain. Another advantage over the earlier tested TZTP derivatives is the position of the iodine atom. Although the previous TZTP derivatives also contained a sp 2 carbon-bound iodine, 


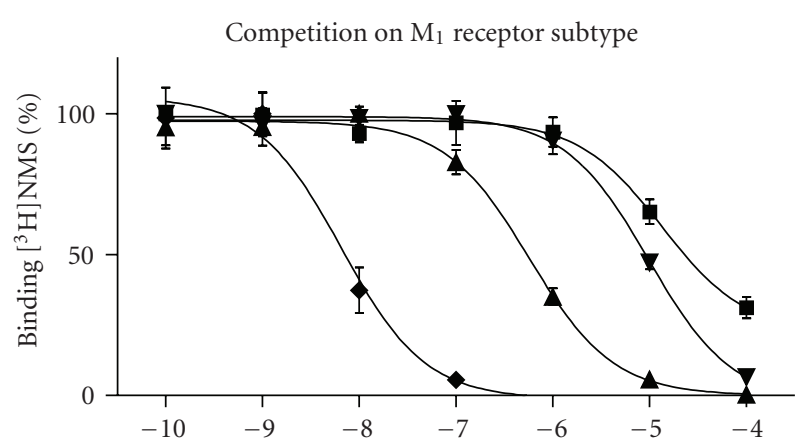

(a)

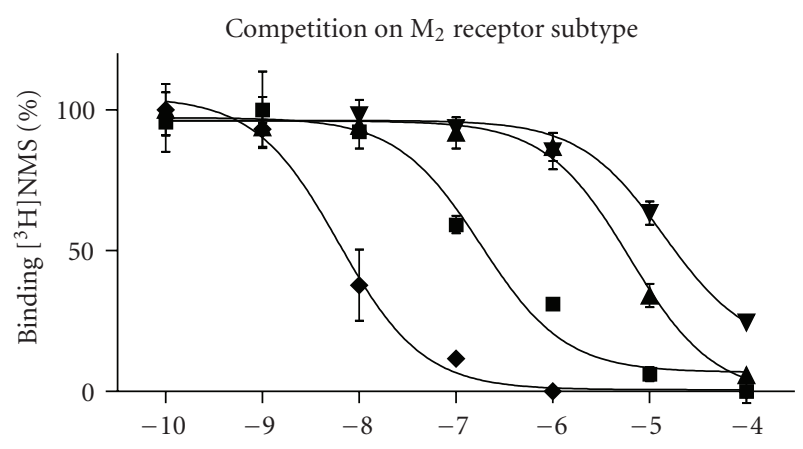

(c)

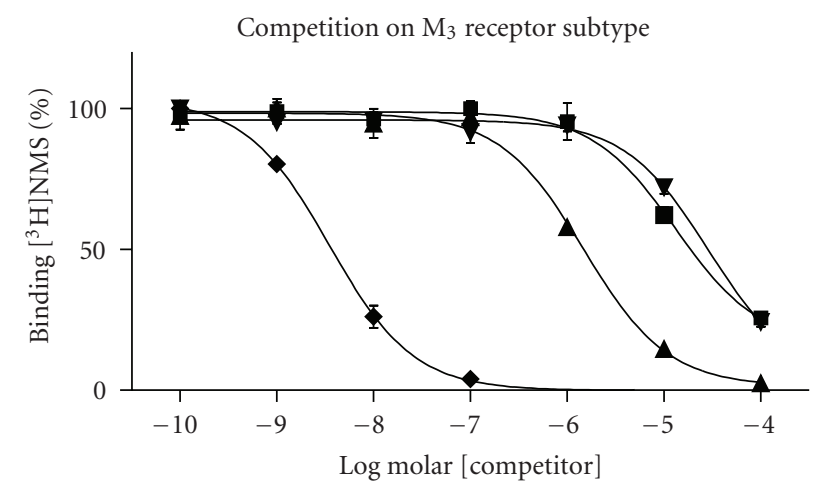

- $6 \beta$-acetoxynortropane

A $6 \beta-4^{\prime}$-iodobenzyl ether of $6 \beta$-nortropinol

$\boldsymbol{\nabla} 6 \beta-4^{\prime}$-iodobenzoate ester of $6 \beta$-nortropinol

- Atropine

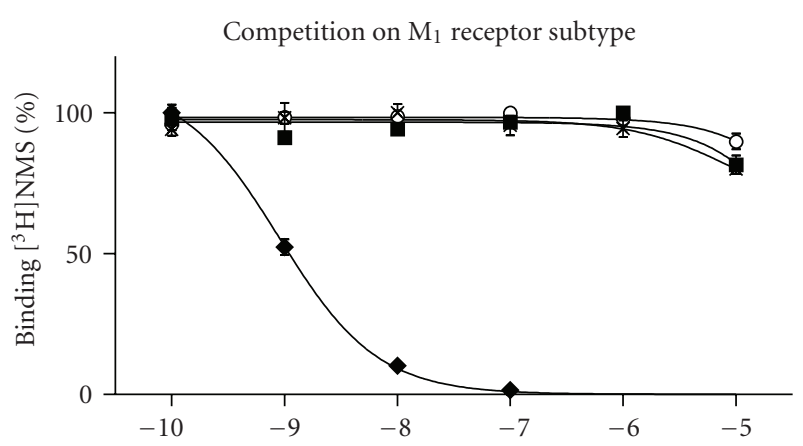

(b)

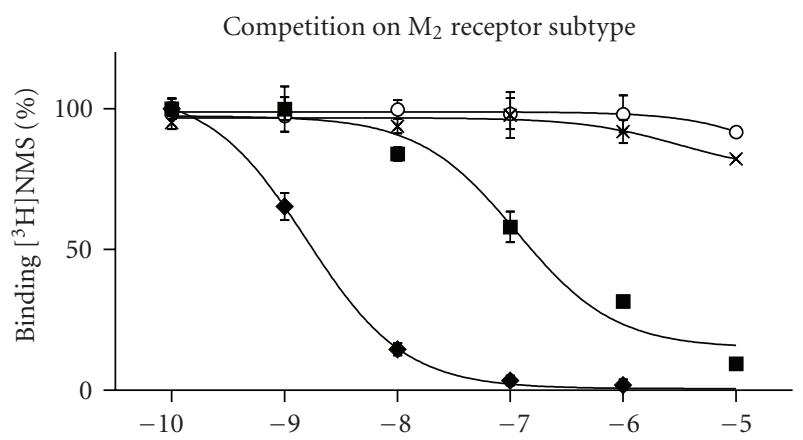

(d)

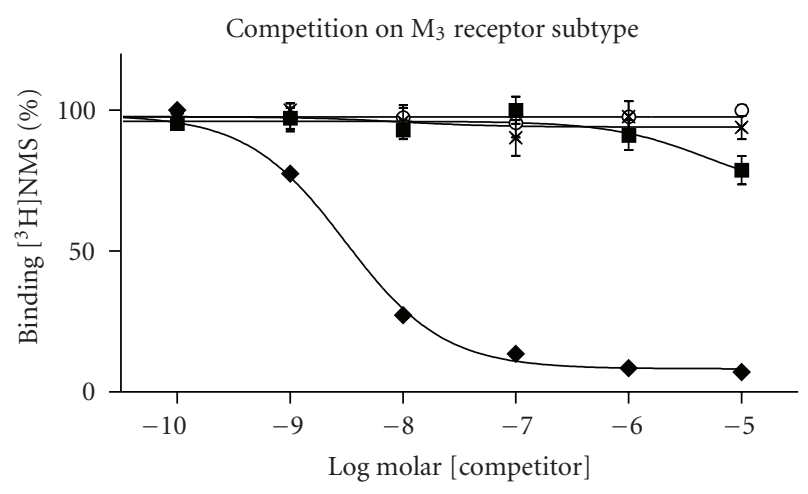

- 6 $\beta$-acetoxynortropane

$\times 3 \beta$-phenyl-6 $\beta$-acetoxynortropane

o $3 \alpha$-hydroxy-3 $\beta$-phenyl- $6 \beta$-acetoxynortropane

- Atropine

(e)

(f)

Figure 2: Competition curves of $6 \beta$-acetoxynortropane (5a, $K_{i}$ for $\mathrm{M}_{2}$ in two separate experiments $88.1 \mathrm{nM}$ and $71.6 \mathrm{nM}$, resp.) and the

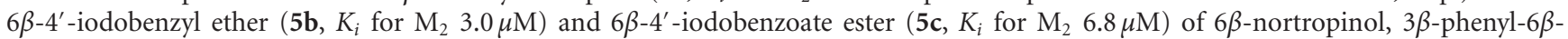
acetoxynortropane (10a, $K_{i}$ for $\mathrm{M}_{2}>1 \mu \mathrm{M}$ ), and $3 \alpha$-hydroxy- $3 \beta$-phenyl- $6 \beta$-acetoxynortropane $\left(10 \mathrm{~b}, K_{i}\right.$ for $\left.\mathrm{M}_{2}>1 \mu \mathrm{M}\right)$ to the binding of $\left[{ }^{3} \mathrm{H}\right] \mathrm{NMS}$ to the muscarinic receptor subtypes $\mathrm{M}_{1}-\mathrm{M}_{3}$. In the curves of (a, c, e) (derivatives $\left.\mathbf{5 a}, \mathbf{5 b}, \mathbf{5} \mathbf{c}\right)$, data are expressed as means $\pm \mathrm{SEM}$ from 3 samples in a range of $1.0 \cdot 10^{-10} \mathrm{M}$ to $1.0 \cdot 10^{-4} \mathrm{M}$ of competitor concentrations. In the curves of (b, d, f) (derivatives 5a, 10a, 10b), data are expressed as means \pm SEM from 4 samples in a range of $1.0 \cdot 10^{-10} \mathrm{M}$ to $1.0 \cdot 10^{-5} \mathrm{M}$ of competitor concentrations. Atropine curves are also displayed as a reference.

this was substituted on the alkenyl side chain, whereas in the present $6 \beta-4^{\prime}$-iodobenzyl ether $(5 \mathbf{b})$ and $6 \beta$-iodobenzoate ester of $6 \beta$-nortropinol $(5 \mathbf{c})$, the iodine is bound to an aromatic sp 2 carbon atom, which favors the in vivo stability and prevents rapid deiodination. Although we did not test iodinated versions of $3 \beta$-phenyl-6 $\beta$-acetoxynortropane (10a) and $3 \alpha$-hydroxy- $3 \beta$-phenyl- $6 \beta$-acetoxynortropane (10b), the phenyl ring would also be the appropriate location for coupling of the iodine atom in these two compounds. Moreover, unlike the earlier described and apparently metabolically unstable TZTP derivatives [25], the $3 \beta$-phenyl$6 \beta$-acetoxynortropane (10a) and $3 \alpha$-hydroxy-3 $\beta$-phenyl-6 $\beta$ - 
acetoxynortropane (10b) should be more metabolically stable due to the direct substitution of the phenyl ring to the tropane skeleton, which is known to have favorable effects on the in vivo stability of tropane-derived radiotracers such as $\left[{ }^{123} \mathrm{I}\right] \mathrm{FP}-\mathrm{CIT}[31,32]$ or $\left[{ }^{123} \mathrm{I}\right] \beta$-CIT $[33]$.

In our competitive binding experiments, the inhibition constant of the original compound $6 \beta$-acetoxynortropane (5a) was substantially higher than the $K_{i}$ that was described by Pei and coworkers [27]. Reasons for this may include differences in the reference tracer, which was $\left[{ }^{3} \mathrm{H}\right] \mathrm{NMS}$ in the present experiments, whereas Pei et al. used $\left[{ }^{3} \mathrm{H}\right]$ quinuclidinyl benzilate $(\mathrm{QNB})$, as well as a difference between rat and human muscarinic receptors. Pei et al. demonstrated a $K_{i}$ of $2.6 \mathrm{nM}$ for $6 \beta$-acetoxynortropane at the muscarinic $\mathrm{M}_{2}$ receptor and very high selectivity ratios over either $M_{1}$ or $M_{3}$ receptors using the tritiated antagonist. In the same study, an even lower inhibition constant was reported by Pei et al. when using the muscarinic agonist $\left[{ }^{3} \mathrm{H}\right]$ oxotremorine as a reference. In our study, using only $\left[{ }^{3} \mathrm{H}\right] \mathrm{NMS}$ but not $\left[{ }^{3} \mathrm{H}\right]$ oxotremorine as a reference, we calculated $K_{i}$ values to the $\mathrm{M}_{2}$ receptor of 71 and $88 \mathrm{nM}$, in two separate series of competitive binding experiments using different protocols, and lower selectivity ratios to $M_{1}$ and $M_{3}$ receptors of 65 and 70, respectively. Nevertheless, such selectivity ratios would be very adequate for imaging of muscarinic $\mathrm{M}_{2}$ receptors in vivo. However, the iodinated analogues that were tested ( $\mathbf{5 b}$ and $\mathbf{5} \mathbf{c}$ ) only showed weak affinity for all three tested muscarinic receptor subtypes, whereas the $K_{i}$ of either $3 \beta$-phenyl-6 $\beta$-acetoxynortropane (10a) or $3 \alpha$ hydroxy-3 $\beta$-phenyl- $6 \beta$-acetoxynortropane (10b) could not be assessed, but proved to be above the micromolar range. We tested the derivatives at a maximal concentration of $10^{-5} \mathrm{M}$, which may be a limitation of the present study, but $K_{i}$ values in the micromolar range or higher were not considered of interest for our purposes. However, it cannot be excluded that iodination of derivative 10a and 10b would result in improved affinities for muscarinic receptors. Also, substitution of the phenyl group at the $3 \alpha$-positition, which is known to have bulk tolerance in tropane-derived radiotracers (and muscarinic receptor antagonists such as atropine, NMS, and benztropine), may improve the in vitro binding characteristics.

In conclusion, we synthesized a series of analogues to $6 \beta$-acetoxynortropane, potentially being of interest for use as radiotracers for in vivo imaging of the muscarinic $\mathrm{M}_{2}$ receptor subtype in neurodegenerative or neuropsychiatric diseases. However, changing the original molecule on the $6 \beta$ - or the $3 \alpha / \beta$-position by substitution of a iodophenyl or phenyl ring severely reduced both the affinity and selectivity of the nortropane for the muscarinic $\mathrm{M}_{2}$ receptor subtype, and therefore, the synthesized analogues are not suitable for use in human SPECT imaging.

\section{References}

[1] D. C. Mash, D. D. Flynn, and L. T. Potter, "Loss of $\mathrm{M}_{2}$ muscarine receptors in the cerebral cortex in Alzheimer's disease and experimental cholinergic denervation," Science, vol. 228, no. 4703, pp. 1115-1117, 1985.
[2] P. Tiraboschi, L. A. Hansen, M. Alford et al., "Cholinergic dysfunction in diseases with LEWY bodies," Neurology, vol. 54, no. 2, pp. 407-411, 2000.

[3] D. S. Baskin, J. L. Browning, F. J. Pirozzolo, S. Korporaal, J. A. Baskin, and S. H. Appel, "Brain choline acetyltransferase and mental function in Alzheimer disease," Archives of Neurology, vol. 56, no. 9, pp. 1121-1123, 1999.

[4] J. L. W. Bosboom, D. Stoffers, and E. C. Wolters, "Cognitive dysfunction and dementia in Parkinson's disease," Journal of Neural Transmission, vol. 111, no. 10-11, pp. 1303-1315, 2004.

[5] E. K. Perry, M. Curtis, and D. J. Dick, "Cholinergic correlates of cognitive impairment in Parkinson's disease: comparisons with Alzheimer's disease," Journal of Neurology Neurosurgery and Psychiatry, vol. 48, no. 5, pp. 413-421, 1985.

[6] J. M. Candy, R. H. Perry, and E. K. Perry, "Pathological changes in the nucleus of Meynert in Alzheimer's and Parkinson's diseases," Journal of the Neurological Sciences, vol. 59, no. 2, pp. 277-289, 1983.

[7] J. T. Coyle, D. L. Price, and M. R. DeLong, "Alzheimer's disease: a disorder of cortical cholinergic innervation," Science, vol. 219, no. 4589, pp. 1184-1190, 1983.

[8] I. Aubert, D. M. Araujo, D. Cecyre, Y. Robitaille, S. Gauthier, and R. Quirion, "Comparative alterations of nicotinic and muscarinic binding sites in Alzheimer's and Parkinson's diseases," Journal of Neurochemistry, vol. 58, no. 2, pp. 529$541,1992$.

[9] S. T. Rouse, S. M. Edmunds, H. Yi, M. L. Gilmor, and A. I. Levey, "Localization of $\mathrm{M}_{2}$ muscarinic acetylcholine receptor protein in cholinergic and non-cholinergic terminals in rat hippocampus," Neuroscience Letters, vol. 284, no. 3, pp. 182$186,2000$.

[10] D. O. Kiesewetter, J. Lee, L. Lang, S. G. Park, C. H. Paik, and W. C. Eckelman, "Preparation of $18 \mathrm{~F}-$-labeled muscarinic agonist with $\mathrm{M}_{2}$ selectivity," Journal of Medicinal Chemistry, vol. 38, no. 1, pp. 5-8, 1995.

[11] M. Maziere, "Cholinergic neurotransmission studied in vivo using positron emission tomography or single photon emission computerized tomography," Pharmacology and Therapeutics, vol. 66, no. 1, pp. 83-101, 1995.

[12] D. W. McPherson, D. L. DeHaven-Hudkins, A. P. Callahan, and F. F. Knapp, "Synthesis and biodistribution of iodine125-labeled 1-azabicyclo[2.2.2] oct-3-yl $\alpha$-hydroxy- $\alpha$-(1-iodo1-propen-3-yl)- $\alpha$-phenylacetate. A new ligand for the potential imaging of muscarinic receptors by single photon emission computed tomography," Journal of Medicinal Chemistry, vol. 36, no. 7, pp. 848-854, 1993.

[13] D. O. Kiesewetter, R. E. Carson, E. M. Jagoda, P. Herscovitch, and W. C. Eckelman, "Using single photon emission tomography (SPECT) and positron emission tomography (PET) to trace the distribution of muscarinic acetylcholine receptor (MACHR) binding radioligands," Life Sciences, vol. 64, no. 67, pp. 511-518, 1999.

[14] P. Sauerberg, P. H. Olesen, S. Nielsen et al., "Novel functional M1 selective muscarinic agonists. Synthesis and structure-activity relationships of 3-(1,2,5-thiadiazolyl)1,2,5,6-tetrahydro-1-methylpyridines," Journal of Medicinal Chemistry, vol. 35, no. 12, pp. 2274-2283, 1992.

[15] L. Ravasi, D. O. Kiesewetter, K. Shimoji, G. Lucignani, and W. C. Eckelman, "Why does the agonist [18F]FP-TZTP bind preferentially to the $\mathrm{M}_{2}$ muscarinic receptor?" European Journal of Nuclear Medicine and Molecular Imaging, vol. 33, no. 3, pp. 292-300, 2006.

[16] R. M. Cohen, T. A. Podruchny, A. L. W. Bokde et al., "Higher in vivo muscarinic-2 receptor distribution volumes in aging 
subjects with an apolipoprotein E- $\varepsilon 4$ allele," Synapse, vol. 49, no. 3, pp. 150-156, 2003.

[17] T. A. Podruchny, C. Connolly, A. Bokde et al., "In vivo muscarinic 2 receptor imaging in cognitively normal young and older volunteers," Synapse, vol. 48, no. 1, pp. 39-44, 2003.

[18] D. M. Cannon, J. K. Klaver, S. K. Gandhi et al., "Genetic variation in cholinergic muscarinic-2 receptor gene modulates $M$ receptor binding in vivo and accounts for reduced binding in bipolar disorder," Molecular Psychiatry, vol. 16, pp. 407-418, 2010.

[19] J. Booij, G. Tissingh, A. Winogrodzka, and E. A. Van Royen, "Imaging of the dopaminergic neurotransmission system using single-photon emission tomography and positron emission tomography in patients with parkinsonism," European Journal of Nuclear Medicine, vol. 26, no. 2, pp. 171-182, 1999.

[20] M. H. Bourguignon, E. K. J. Pauwels, C. Loc'h, and B. Mazière, "Iodine-123 labelled radiopharmaceuticals and single-photon emission tomography: a natural liaison," European Journal of Nuclear Medicine, vol. 24, no. 3, pp. 331-344, 1997.

[21] F. J. Diaz-Corrales, S. Sanz-Viedma, D. Garcia-Solis, T. Escobar-Delgado, and P. Mir, "Clinical features and I-FPCIT SPECT imaging in drug-induced parkinsonism and Parkinson's disease," European Journal of Nuclear Medicine and Molecular Imaging, vol. 37, no. 3, pp. 556-564, 2010.

[22] N. A. Lassen, "A reappraisal of the relative merits of SPET and PET in the quantitation of neuroreceptors: the advantage of a longer half-life!," European Journal of Nuclear Medicine, vol. 23, no. 1, pp. 1-4, 1996.

[23] S. A. Ross and J. P. Seibyl, "Research applications of selected 123I-labeled neuroreceptor SPECT imaging ligands," Journal of Nuclear Medicine Technology, vol. 32, no. 4, pp. 209-214, 2004.

[24] S. Vallabhajosula, Molecular Imaging: Radiopharmaceuticals for PET and SPECT, Springer, Berlin, Germany, 2009.

[25] R. J. J. Knol, T. Doornbos, J. C. Van Den Bos et al., "Synthesis and evaluation of iodinated TZTP-derivatives as potential radioligands for imaging of muscarinic $M$ receptors with SPET," Nuclear Medicine and Biology, vol. 31, no. 1, pp. 111123, 2004.

[26] K. Nobuhara, C. Halldin, H. Hall et al., “Z-IQNP: a potential radioligand for SPECT imaging of muscarinic acetylcholine receptors in Alzheimer's disease," Psychopharmacology, vol. 149, no. 1, pp. 45-55, 2000.

[27] X. F. Pei, T. H. Gupta, B. Badio, W. L. Padgett, and J. W. Daly, "6 6 -acetoxynortropane: a potent muscarinic agonist with apparent selectivity toward M-receptors," Journal of Medicinal Chemistry, vol. 41, no. 12, pp. 2047-2055, 1998.

[28] R. Robinson, "A synthesis of tropinone," Journal of the Chemical Society, Transactions, vol. 111, pp. 762-768, 1917.

[29] J. W. Boja, M. J. Kuhar, T. Kopajtic et al., "Secondary amine analogues of $3 \beta$ - $\left(4^{\prime}\right.$-substituted phenyl $)$ tropane- $2 \beta$-carboxylic acid esters and $\mathrm{N}$-norcocaine exhibit enhanced affinity for serotonin and norepinephrine transporters," Journal of Medicinal Chemistry, vol. 37, no. 8, pp. 1220-1223, 1994.

[30] M. Koreeda and J. Luengo, "A new reagent for the selective, high-yield $\mathrm{N}$-dealkylation of tertiary amines: improved syntheses of naltrexone and nalbuphine," Journal of Organic Chemistry, vol. 49, no. 11, pp. 2081-2082, 1984.

[31] J. Booij, G. Andringa, L. J. M. Rijks et al., "[ $\left.{ }^{123} \mathrm{I}\right]$ FP-CIT binds to the dopamine transporter as assessed by biodistribution studies in rats and SPECT studies in MPTP-lesioned monkeys," Synapse, vol. 27, no. 3, pp. 183-190, 1997.

[32] J. L. Neumeyer, S. Wang, Y. Gao et al., "N- $\omega$-fluoroalkyl analogs of (1R)-2 $\beta$-carbomethoxy-3 $\beta$-(4-iodophenyl)- tropane
( $\beta$-CIT): radiotracers for positron emission tomography and single photon emission computed tomography imaging of dopamine transporters," Journal of Medicinal Chemistry, vol. 37, no. 11, pp. 1558-1561, 1994.

[33] S. Wang, Y. Gao, M. Laruelle et al., "Enantioselectivity of cocaine recognition sites: binding of (1S)- and (1R)- $2 \beta$ carbomethoxy-3 $\beta$-(4-iodophenyl)tropane $(\beta$-CIT) to monoamine transporters," Journal of Medicinal Chemistry, vol. 36, no. 13, pp. 1914-1917, 1993. 


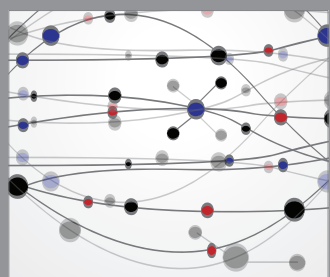

The Scientific World Journal
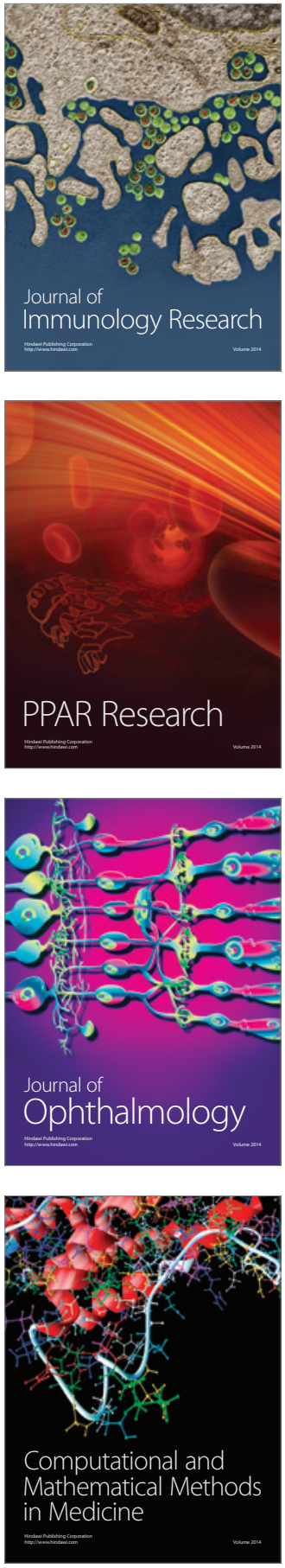

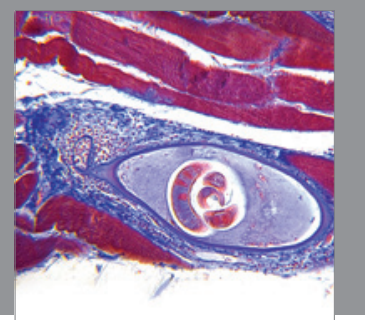

Gastroenterology

Research and Practice
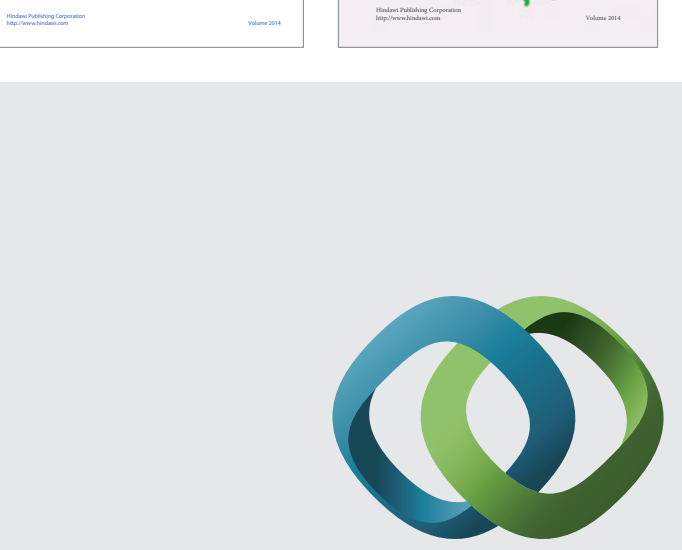

\section{Hindawi}

Submit your manuscripts at

http://www.hindawi.com
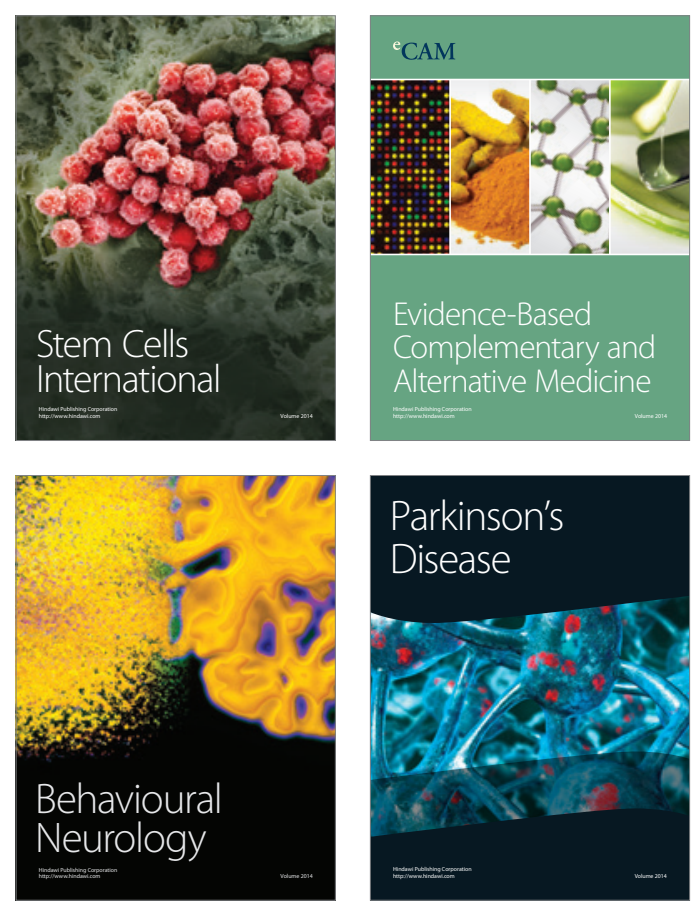

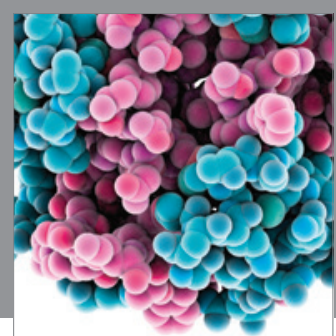

Journal of
Diabetes Research

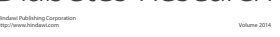

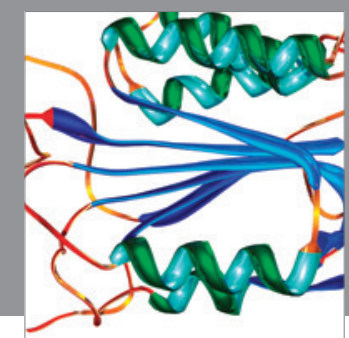

Disease Markers
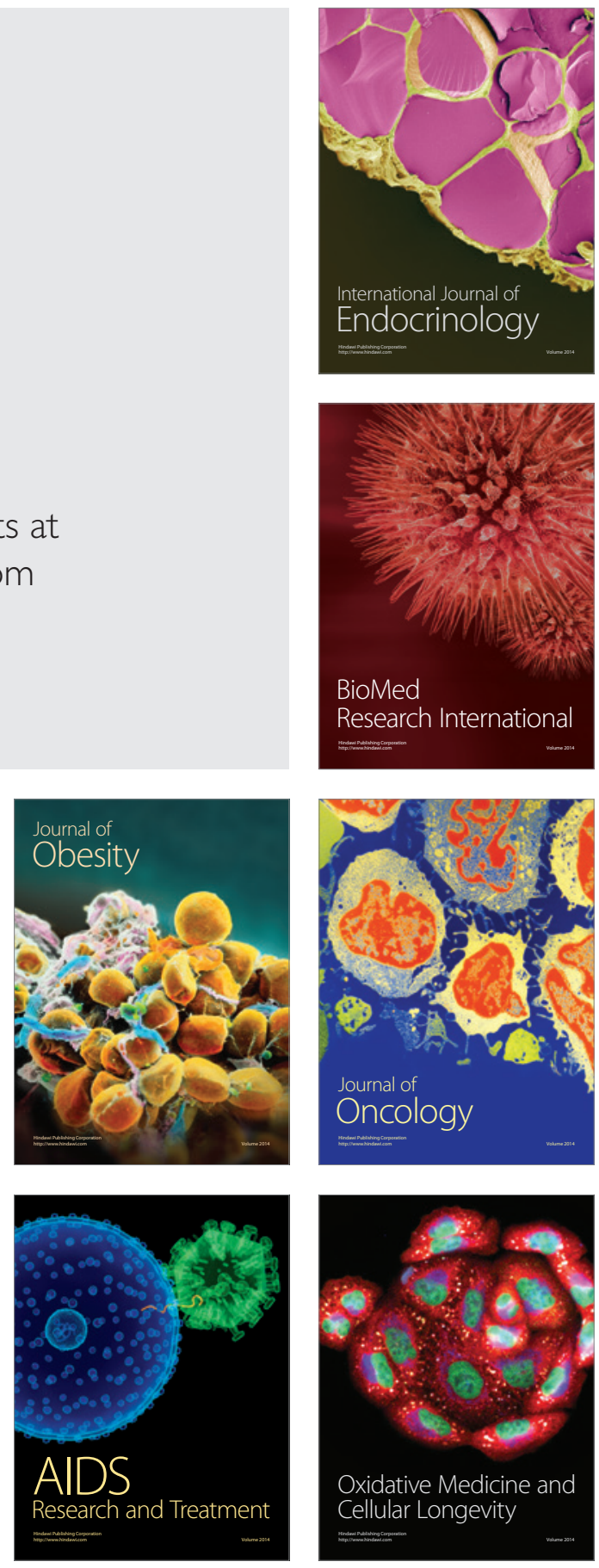